\title{
Evaluation of heavy metal and microbial content of a multicomponent herbal preparation
}

\author{
Hidayah Ayodeji OLUMOH-ABDUL ${ }^{1 *}$, Rashidat Oluwafunke AYANNIYI ${ }^{1}$, Fatimoh \\ Idowu OJUADE ${ }^{1}$, Haishat Yetunde OLUFADI-AHMED ${ }^{2}$ and Zainab Oluwatosin \\ ONIBON $^{1}$
}

${ }^{1}$ Department of Pharmacology and Toxicology; ${ }^{2}$ Department of Microbiology and Biotechnology; Faculty of Pharmaceutical Sciences, University of Ilorin, Ilorin. Kwara State, Nigeria.

Received 29 $9^{\text {th }}$ June 2020; Accepted $9^{\text {th }}$ November 2020

\begin{abstract}
Herbal mixtures are extensively consumed globally for medicinal use due to the belief that they are safe and readily accessible. The herbal preparation (SHM), evaluated in this study, is made up of 7 plants found in Nigeria and it is used internally and externally for varieties of disease conditions. The heavy metals and microbial content of SHM was evaluated. Three batches of the SMH were analyzed for presence of heavy metals using Atomic Absorption Spectrophotometer. The microbial load was also evaluated by determining the total viable yeast, mould and coliform bacteria count. The metal and microbial content of the samples were compared with WHO permissible limits and differences in concentration among the batches were determined. Fe $(0.010-0.100 \mathrm{mg} / \mathrm{L})$ and $\mathrm{Zn}(0.010-0.030 \mathrm{mg} / \mathrm{L})$ detected were significantly $(\mathrm{P}<0.05)$ lower than the permissible limits while $\mathrm{Cu}, \mathrm{Pb}$ and $\mathrm{Cd}$ were absent. A batch had total yeast and mould count $\left(4.95 \times 10^{3} \mathrm{Cfu} / \mathrm{mL}\right)$ above the permissible limit whereas the other batches were below the limit. Microorganisms (yeasts, mould like Aspergillus flavus and Rhizoctonia solani) were present in all the batches and hence SHM may not be safe for internal use.
\end{abstract}

Keywords: Herbal mixtures, Heavy metals, Microbial load, Atomic absorption spectrophotometer

\section{INTRODUCTION}

The use of herbal mixtures around the world is on the rise (about $80 \%$ of the world, as at 2013) [1]. This increase is spurred by the belief that herbal products are safe and readily accessible as compared to synthetic drugs that are not only costly but also have adverse effects [2]. However, recent studies have shown fluctuating amounts of contaminations ranging from heavy metals, micro-organisms and other adulterants in herbs and herbal products from different parts of the world, indicating need for continuous evaluation of the herbal products [2-4]. Some of these studies reported microbial and metal content beyond the WHO permissible limits [5].

The acceptance of medicinal herbal products for improving health is on the increase due to their availability and affordability. Therefore, analyzing these products for their heavy metal content and microbial load has become imperative. The level of heavy metal and microbial concentration has implications on the general

*Correspondence. E-mail: ayodeji.pharm@yahoo.com Tel: +234-8032273917.

ISSN 0189-8442

(cc) BY-No 2020. Published by Faculty of Pharmaceutical Sciences, University of Jos, Nigeria. Under Creative Commons Attribution-NonCommercial 4.0 International License. https://creativecommons.org/licenses/by-nc/4.0/ 
health of humans as they can cause systemic damage where they are above approved limits and even where in low limits, their bio accumulative property may render them detrimental $[2,5]$.

Though oral medicines are not required to be absolutely sterile, there is a limit to the number of microorganisms and heavy metal contaminants these preparations should contain. The presence of high microbial count in any preparation can lead to the proliferation of such organisms within the preparation leading to spoilage and importantly they can cause infections in both healthy and immunecompromised people [5]. Although heavy metals are naturally occurring elements, continued exposure of herbal products to their constituents could lead to the birth of a variety of ailments due to their wide and prolonged use [6].

The World Health Organization (WHO) and the Food and Agriculture Organization (FAO) have jointly proposed acceptable levels of toxic substances that can be ingested on a weekly basis called the Provisional Tolerable Weekly Intake (PTWI), generally used for contaminants that may accumulate in the body [3]. Despite this, most studies have reported the concentration of heavy metals and presence of microbial loads beyond the permisible ranges [7-8]. This may be due in part to lack of enough knowledge by traditional practitioners of the guidelines for quality assurance and control of herbal medicine that have been put in place by WHO, resulting in medications with various types of heavy metal and microbial contamination [9]. Consequently, there are many cases of heavy metal poisoning and microbial contamination most of which are, sadly, underreported or not reported. Thus there is a continuous need for constant evaluation and investigation of herbal products to validate the quality and safety for human consumption.

This present study evaluated a commonly used herbal preparation in Nigeria represented as $\mathrm{SMH}$ for the purpose of this study. SMH is indicated for treatment of several conditions like; chicken pox, small pox and measles, viral infections, malaria, diarrhea, ulcers, liver inflammation, bacterial infections, inhibition of platelet aggregation, stomach cancer, aphrodisiac, obesity, arthritis, diabetes, stomach ache, pile, warts, sores, laxative among others. The herbal product contains 7 herbal constituents (Allium sativum, Combretum misrantum, Ficus carica, Nauclea latifolia, Sterculia urens, Tetrapleura tetraptera, Xylopia aromatica); the various indications are believed to be due to the individual or synergistic activities of the different constituents that make up the herbal preparation. The product is indicated for use in both adults and children, consumed either internally or applied externally. However, reports on the microbial and heavy metal content of SMH herbal mixture are not available in literature. This study therefore evaluated the heavy metal content and microbial content of SHM.

\section{EXPERIMENTAL METHODS}

Materials. Buck Accusys model 211 Atomic Absorption Spectrophotometer (AAS) equipped with corresponding hollow cathode lamp (Lead, Cadmium and Iron) at the time of analysis, De-ionized water, Muller Hilton Agar, Sabouraud dextrose agar, Microscope (LABOMED USA LX 300), Autoclave, Vortex mixer and incubator. All reagents used were supplied by the laboratory and of analytical grade.

Sample collection. Based on availability, using convenience sampling, three batches of $\mathrm{SMH}$ were purchased from registered Pharmacies in different locations of Lagos State as supplied by manufacturer in original packages. Manufacturing date, expiry date, batch number and National Agency for Food and Drug Administration and Control (NAFDAC) registration numbers were examined. Ethical clearance was obtained 
from the Ethical Review Committee of the University of Ilorin, Ilorin, Nigeria. The experiment was given an approval number UERC/ASN/2019/1859.

Preparation of calibration curve. Deionized water was used in preparing solutions of each of the metals to be tested for. Stock solution was prepared by dissolving each solid metal sample $1.0 \mathrm{~g}$ in $10 \mathrm{~mL} \mathrm{1:1} \mathrm{nitric} \mathrm{acid} \mathrm{solution,}$ which was transferred into $1000 \mathrm{~mL}$ volumetric flask and made up with deionized water. Standard solutions were made from each metal stock solution of $1000 \mathrm{mg} / \mathrm{L}$. Calibration curve was prepared by successive serial dilution of the stock solution. Working standard solutions of iron $(\mathrm{Fe})$, lead $(\mathrm{Pb})$, cadmium $(\mathrm{Cd})$, zinc $(\mathrm{Zn})$ and copper $(\mathrm{Cu})$ were used for comparison. A $100 \mathrm{~mL}$ quantity of standard solution of each metal was adjusted to $\mathrm{pH} 2.5$ by adding $1 \mathrm{M}$ nitric acid. Each blank and standard solution was transferred into individual $250 \mathrm{~mL}$ separating funnel. Ammonium pyrrolidine dithiocarbamate (1 $\mathrm{mL}$ ) was added followed by $10 \mathrm{~mL}$ methyl isobutyl ketone then solution was shaken vigorously for 2 minutes and allowed to settle. Aqueous layer was discarded while the organic layer was aspirated directly into the flame and absorbance was recorded using atomic absorption spectrophotometer BUCK ACCUSYS 211 model equipped with each hollow cathode lamp at $283.2 \mathrm{~nm}, 248.3 \mathrm{~nm}$, $228.8 \mathrm{~nm}, \quad 327.4 \mathrm{~nm}$, and $213.9 \mathrm{~nm}$ wavelengths for lead, iron, cadmium, copper and zinc respectively. The nebulizer, atomizer and burner were flushed each time with deionized water and after every sample, aspirated before the next. Stability of equipment was checked at intervals by introducing highest working standard solution and blank [10-11].

Sample pretreatment (aqua-regia hot plate method). A quantity of $3 \mathrm{~mL}$ of $\mathrm{SMH}$ was measured into a digestion flask and digested with $12 \mathrm{~mL}$ of aqua-regia $\left(\mathrm{HNO}_{3}: \mathrm{HCl}\right)$ in the ratio $1: 3$ on a hot plate under a fume cupboard at $80^{\circ} \mathrm{C}$ until dense white fumes appeared. The flask was allowed to cool then little quantity of deionized water was added. The herbal mixture was digested again until clear solution was obtained. This solution was left to cool and filtered into $100 \mathrm{~mL}$ volumetric flask then made up to mark with deionized water. This procedure was repeated three times [12-13]. Same procedure as above was carried out on the other batches.

Sample analysis. Digested samples were analyzed using atomic absorption spectrophotometer BUCK ACCUSYS 211 model equipped with each hollow cathode lamp at $283.2 \mathrm{~nm}, 248.3 \mathrm{~nm}, 228.8 \mathrm{~nm}, 327.4$ $\mathrm{nm}$, and $213.9 \mathrm{~nm}$ wavelengths for $\mathrm{Pb}, \mathrm{Fe}, \mathrm{Cd}$, $\mathrm{Cu}$, and $\mathrm{Zn}$ respectively. Absorbance for each metal in each digested sample was recorded. Concentration of each metal from sample was determined from calibration curve.

Microbial analysis. SHM was shaken properly to ensure a uniform distribution of the content. One milliliter of the suspension was homogenized with $9 \mathrm{ml}$ of distilled water and shaken vigorously. One milliliter of this suspension was then transferred to another tube until a tenfold serial dilution was obtained. Molten nutrient agar was sterilized at $121^{\circ} \mathrm{C}$ for 15 minutes and cooled to about $45^{\circ} \mathrm{C}$ for bacterial count and Sabouraud dextrose agar for fungal count. The mixture solidified at room temperature. The plates were incubated at $37^{\circ} \mathrm{C}$ for 24 hours and $25^{\circ} \mathrm{C}$ for $3-5$ days for bacterial and fungal cells respectively. Colonies were counted using a digital colony counter and plates having between 25 and 250 colonies were counted as colony forming units per milliliter (cfu/ml) [14]. Morphological characteristics and staining with microscopic identification were carried out on the fungal isolates. Microbial load was translated as $\mathrm{Cfu} / \mathrm{mL}$ of sample [5].

Statistical analysis. Results were presented as the mean \pm S.E.M. Data were analyzed using Graphpad version 8.01. Statistical analysis was 
carried out using ANOVA and statistical significance was taken at $\mathrm{P}<0.05$.

\section{RESULTS}

Heavy metal content. Traces of heavy metals (Fe and $\mathrm{Zn}$ ) were found in samples of the herbal mixture investigated in this study. The quantitative analysis revealed that copper, lead and cadmium were undetectable by the atomic absorption spectrophotometer (AAS) in all batches of SHM. Iron ( $\mathrm{Fe})$ and Zinc $(\mathrm{Zn})$ were present at varying concentrations across the batches analyzed. The concentration of $\mathrm{Fe}$ ranged between $0.010-0.100 \mathrm{mg} / \mathrm{L}$ while $\mathrm{Zn}$ was between $0.010-0.030 \mathrm{mg} / \mathrm{L}$ across the three batches. Batch $\mathrm{C}$ had the highest concentration of $\mathrm{Fe}$ and $\mathrm{Batch} \mathrm{B}$ the highest for $\mathrm{Zn}$ while Batch A recorded the least concentration of both Fe and $\mathrm{Zn}$. (Table 1)

The concentrations of heavy metals obtained from each sample were compared with the
WHO permissible limits of $0.1 \mathrm{mg} / \mathrm{L}, 20 \mathrm{mg} / \mathrm{L}$, $0.3 \mathrm{mg} / \mathrm{L}, 50.0 \mathrm{mg} / \mathrm{L}$, and $10 \mathrm{mg} / \mathrm{L}$ for $\mathrm{Fe}, \mathrm{Cu}$, $\mathrm{Cd}, \mathrm{Zn}$ and $\mathrm{Pb}$ respectively (WHO, 2007). Fe and $\mathrm{Zn}$ were present but in ranges within the WHO permissible limits. The highest concentration of Fe recorded was $0.1 \mathrm{mg} / \mathrm{kg}$ which is not significantly $(\mathrm{P}<0.05)$ when compared to the permissible limit of $0.1 \mathrm{mg} / \mathrm{L}$, $\mathrm{Zn}$ had the highest concentration of 0.030 $\mathrm{mg} / \mathrm{L}$ with a permissible limit of $50 \mathrm{mg} / \mathrm{L}$. Cu, $\mathrm{Cd}$ and $\mathrm{Pb}$ were absent in the entire sample as presented in tables 2, 3 and 4.

Microbial content. Total viable count and combined total yeast and mould count were determined (Table 5). After incubation, all plates containing 25-250 colonies were considered and their colony forming units per milliliter calculated. Counts above 250 are considered too numerous to count largely because it may be impossible to tell if colonies are separated [15].

Table 1: Concentration of $\mathrm{Fe}, \mathrm{Cu}, \mathrm{Zn}, \mathrm{Pb}$ and $\mathrm{Cd}$ in Batches 1, 2, and $3 \mathrm{SHM}$ samples

\begin{tabular}{cccccc}
\hline \multirow{2}{*}{ Samples } & \multicolumn{5}{c}{ Concentration $(\mathrm{mg} / \mathrm{L})$} \\
\cline { 2 - 6 } & $(\mathrm{Fe})$ & $(\mathrm{Zn})$ & $(\mathrm{Cu})$ & $(\mathrm{Pb})$ & $(\mathrm{Cd})$ \\
\hline $\mathrm{A} 1$ & $0.015 \pm 0.005$ & $0.020 \pm 0.000$ & 0.000 & 0.000 & 0.000 \\
$\mathrm{~A} 2$ & $0.030 \pm 0.010$ & $0.020 \pm 0.000$ & 0.000 & 0.000 & 0.000 \\
$\mathrm{~A} 3$ & $0.030 \pm 0.000$ & $0.020 \pm 0.000$ & 0.000 & 0.000 & 0.000 \\
$\mathrm{~B} 1$ & $0.060 \pm 0.010$ & $0.020 \pm 0.000$ & 0.000 & 0.000 & 0.000 \\
$\mathrm{~B} 2$ & $0.025 \pm 0.005$ & $0.030 \pm 0.000$ & 0.000 & 0.000 & 0.000 \\
$\mathrm{~B} 3$ & $0.015 \pm 0.005$ & $0.010 \pm 0.000$ & 0.000 & 0.000 & 0.000 \\
$\mathrm{C} 1$ & $0.100 \pm 0.000$ & $0.010 \pm 0.000$ & 0.000 & 0.000 & 0.000 \\
$\mathrm{C} 2$ & $0.055 \pm 0.005$ & $0.025 \pm 0.005$ & 0.000 & 0.000 & 0.000 \\
$\mathrm{C} 3$ & $0.010 \pm 0.000$ & $0.020 \pm 0.000$ & 0.000 & 0.000 & 0.000 \\
\hline \multicolumn{6}{c}{ Values mean \pm S.E.M $(\mathrm{n}=3)$} \\
\end{tabular}

Table 2: Comparison of concentrations of $\mathrm{Fe}, \mathrm{Cu}, \mathrm{Zn}, \mathrm{Pb}$ and $\mathrm{Cd}$ present in the $\mathrm{SHM}$ with the Permissible Limits for Batch 1 samples

\begin{tabular}{cccccc}
\hline \multirow{2}{*}{ Samples } & \multicolumn{5}{c}{ Concentrations $(\mathrm{mg} / \mathrm{L}) /$ Permissible limits $(\mathrm{mg} / \mathrm{L})$} \\
\cline { 2 - 6 } & $\mathrm{Fe}$ & $\mathrm{Cu}$ & $\mathrm{Zn}$ & $\mathrm{Pb}$ & $\mathrm{Cd}$ \\
\hline $\mathrm{A} 1$ & $0.015 \pm 0.005 / 0.100$ & $0.000 / 20.000$ & $0.020 \pm 0.000 / 50.000$ & $0.000 / 10.000$ & $0.000 / 0.300$ \\
$\mathrm{~A} 2$ & $0.060 \pm 0.010 / 0.100$ & $0.000 / 20.000$ & $0.020 \pm 0.000 / 50.000$ & $0.000 / 10.000$ & $0.000 / 0.300$ \\
$\mathrm{~A} 3$ & $0.100 \pm 0.000 / 0.100$ & $0.000 / 20.000$ & $0.010 \pm 0.000 / 50.000$ & $0.000 / 10.000$ & $0.000 / 0.300$ \\
\hline \multicolumn{5}{c}{ Values mean \pm S.E.M $(\mathrm{n}=3)$}
\end{tabular}

Table 3: Comparison of concentrations of $\mathrm{Fe}, \mathrm{Cu}, \mathrm{Zn}, \mathrm{Pb}$ and $\mathrm{Cd}$ present in the SHM with the Permissible Limits for Batch 2 samples

\begin{tabular}{cccccc}
\hline \multirow{2}{*}{ Samples } & \multicolumn{5}{c}{ Concentrations $(\mathrm{mg} / \mathrm{L}) /$ Permissible limits $(\mathrm{mg} / \mathrm{L})$} \\
\cline { 2 - 6 } & $\mathrm{Fe}$ & $\mathrm{Cu}$ & $\mathrm{Zn}$ & $\mathrm{Pb}$ & $\mathrm{Cd}$ \\
\hline $\mathrm{B} 1$ & $0.030 \pm 0.010 / 0.100$ & $0.000 / 20.000$ & $0.020 \pm 0.000 / 50.000$ & $0.000 / 10.000$ & $0.000 / 0.300$ \\
$\mathrm{~B} 2$ & $0.025 \pm 0.005 / 0.100$ & $0.000 / 20.000$ & $0.030 \pm 0.000 / 50.000$ & $0.000 / 10.000$ & $0.000 / 0.300$ \\
$\mathrm{~B} 3$ & $0.055 \pm 0.005 / 0.100$ & $0.000 / 20.000$ & $0.025 \pm 0.005 / 50.000$ & $0.000 / 10.000$ & $0.000 / 0.300$ \\
\hline \multicolumn{5}{c}{ Values mean \pm S.E.M $(\mathrm{n}=3)$}
\end{tabular}


Table 4: Comparison of concentrations of $\mathrm{Fe}, \mathrm{Cu}, \mathrm{Zn}, \mathrm{Pb}$, and $\mathrm{Cd}$ with permissible limits for Batch 3 samples

\begin{tabular}{cccccc}
\hline \multirow{2}{*}{ Samples } & $\mathrm{Fe}$ & $\mathrm{Cu}$ & $\mathrm{Zn}$ & $\mathrm{Pb}$ & $\mathrm{Cd}$ \\
\cline { 2 - 6 } & $0.030 \pm 0.000 / 0.100$ & $0.000 / 20.000$ & $0.020 \pm 0.000 / 50.000$ & $0.000 / 10.000$ & $0.000 / 0.300$ \\
$\mathrm{~A} 1$ & $0.015 \pm 0.005 / 0.100$ & $0.000 / 20.000$ & $0.010 \pm 0.000 / 50.000$ & $0.000 / 10.000$ & $0.000 / 0.300$ \\
$\mathrm{~B} 1$ & $0.010 \pm 0.000 / 0.100$ & $0.000 / 20.000$ & $0.020 \pm 0.000 / 50.000$ & $0.000 / 10.000$ & $0.000 / 0.300$ \\
\hline \multicolumn{5}{c}{ Values mean \pm S.E.M $(\mathrm{n}=3)$}
\end{tabular}

Table 5: Table showing microbial count in the Batches of SMH

\begin{tabular}{ccc}
\hline Batch & $\begin{array}{c}\text { Total viable } \\
\text { count }(\mathrm{cfu} / \mathrm{ml})\end{array}$ & $\begin{array}{c}\text { Combined total yeast and } \\
\text { mould count (cfu/ml) }\end{array}$ \\
\hline A & Nil & $4.95 \times 10^{3}$ \\
B & Nil & Nil \\
C & Nil & Nil \\
AHPA Limits & $10^{4}$ & $10^{3}$ \\
WHO limits for herbal material for & $10^{5}$ & $10^{3}$ \\
internal use & & $10^{3}$ \\
Safety USP limits for products & $10^{4}$ & \\
containing botanical ingredients & &
\end{tabular}

\section{DISCUSSION}

Microbial and chemical contamination may render herbal mixtures unsafe; these contaminations may result from handling/production process, cross contamination from other materials and/or the soil in which the herbs are planted [16].

Quantitative analysis of samples of $\mathrm{SMH}$ in the present study revealed that all the batches examined had Iron present; the highest concentration of $0.10 \mathrm{mg} / \mathrm{L}$ was found in Batch C. This range was lower than the permissible limits set by WHO as well as AHPA standard [9, 17]. Although iron was present in all the batches of SHM analyzed but not at a concentration that will manifest immediate toxicity. Previous studies have recorded iron concentration below the standard permissible limits [18-19]. However, heavy metal concentrations could reach levels with potentially hazardous effects in humans due to their cumulative properties. [20]. Iron is a known biologically active metal with vital functions in the human body including oxygen supply, blood formation and immunity. However when taken at high concentration adverse reactions like dizziness, nausea and vomiting, diarrhea, joints pain, shock, and liver damage may occur [21]. Iron toxicity has been reported to have an adverse effect on various metabolic functions and cardiovascular system [22].

Zinc was also found in all batches of SHM at a concentration range of 0.010- 0.030 $\mathrm{mg} / \mathrm{L}$ which was lower than the WHO permissible limit of $50.0 \mathrm{mg} / \mathrm{L}$ [9]. This corroborates similar studies that recorded $\mathrm{Zn}$ level below permissible limits in investigated herbal product [4, 23]. Zinc is an essential trace element necessary for proper growth, blood clotting, thyroid function, and protein and DNA synthesis [4]. Little information is available on $\mathrm{Zn}$ toxicity; high zinc intake beyond permissible limits produces both acute and cumulative toxic effects in human [24]. Copper, lead and cadmium were undetectable in all batches of SHM.

The analysis of microbial load of SHM showed no bacterial growth in all batches examined; this may be attributed to the antimicrobial properties of four out of the 7 herbal components of SHM which include: Allium sativum [25], Combretum misrantum[26], Nauclea latifolia [27] and Sterculia uren [28]. The individual or synergistic effect(s) of these herbs may have inhibited the growth of bacteria. More so, SHM itself is indicated for the treatment of bacterial infections. All three batches had less than 25 bacteria colonies per plate which means they are too low to be significant and 
fall within the safety limit set by all regulatory bodies referenced. However, the combined total yeast and mould count for batch $A$ displayed a value higher than the safety limits for WHO, AHPA and USP while batches B and $\mathrm{C}$ had very low counts thereby falling below the safety limits for herbal products [9, 29-31]. Morphological characteristics, staining and microscopic identification of the isolated fungal cells showed that $100 \%$ of the cells are yeast cells. Yeast contamination in an herbal product just like any pharmaceutical preparation; represent a potential hazard because it may cause product spoilage that may affect therapeutic properties of the said product. It may also possess some enzymes which may be of a health hazard to the final users of the product [32].

Some reports on herbal medicines in Nigeria have documented only the presence of bacteria in the product which was devoid of fungal/ yeast cells [20] while others have documented the presence of bacteria, fungi/ yeast and even parasites in the tested herbs [33], the present research shows only contamination by yeast cells. These molds when present in herbal products may points to improper collection, storage and transportation processes.

The results of this study corroborate those of previous reports that have shown fluctuating amounts of heavy metals and presence of microorganisms in herbs and herbal products from different parts of the world. There is need for adoption of good manufacturing process during collection and production of herbal medicines to reduce contamination $[2,4,5,16]$.

Conclusion. The results of this study indicate the presence of zinc and iron in all batches of SHM analyzed. However, the concentrations did not exceed the permissible limits despite the significant batch-to-batch variations. The total viable count for all the three batches of SMH fall below set limits. Precautions should be taken when $\mathrm{SMH}$ is to be administered orally.

\section{REFERENCES}

1. World Health Organization (2013). Traditional Medicine Strategy: 2014-2023. Retrieved September, 2014

2. Alwakeel, S.S (2008). Microbial and heavy metals contamination of herbal medicines. Research journal of microbiology, 3(12):683-691.

3. Kosalec, I.; Cvek, J. and Tomić, S. (2009). Contaminants of Medicinal Herbs and Herbal Products. Archives of Industrial Hygiene and Toxicology, 60(4):485-501.

4. Dghaim, R.; Al Khatib, S.; Rasool, H. and Ali Khan, M. (2015). Determination of Heavy Metals Concentration in Traditional Herbs Commonly Consumed in the United Arab Emirates. Journal of Environmental and Public Health,1-6.

5. Oluwatoyin, A. I. and Adebayo, L. (2016). Assessment of the microbial quality of some oral liquid herbal medicines marketed in Ile-Ife, Southwestern Nigeria. African Journal of Microbiology Research, 10(38), 1618-1624.

6. Obi, E.; Akunyili, DN.; Ekpo, B. and Orisakwe, O. (2006). Heavy metal hazards of Nigerian herbal remedies. Science of Total Environment, 31(369):3541.

7. Hina, B.; Rizwani, G.H. and Nazeem, S. (2011). Determination of toxic metals in some herbal drugs through atomic absorption spectroscopy. Pakistan journal of Pharmaceutical Sciences, 24(3)

8. Shamsa, F.; Monsef, H.; Ghamooshi, R. and Verdianrizi, M. (2008). Spectrophotometric determination of total alkaloids in some Iranian medicinal plants. Thai J Pharm Sci. (32): 17-20.

9. World Health Organization (2007). WHO Guidelines for Assessing Quality of Herbal Medicines with Reference to Contaminants and Residues, Geneva, World Health Organization.

10. Enuh, H.; Oragwu, C.; Okeke, C.; Elu, C. and Orisakwe, O, (2012). Semen Abnormality and Nigeria Herbal Remedies: A Preliminary Investigation. The Internet Journal of Toxicology, $8(2)$.

11. Bakare-Odunola, M.T. and Mustapha, K.B (2014). Identification of heavy metals in local drinks in Northern Zone of Nigeria. Journal of Toxicology and Environmental Health Sciences, 6(7):126-131.

12. Kojuncu, Ý.; Bundalevska, J. M.; Ay, Ü.; Čundeva, K.; Stafilov, T. and Akçin, G. (2004). Atomic Absorption Spectrometry Determination of $\mathrm{Cd}, \mathrm{Cu}, \mathrm{Fe}, \mathrm{Ni}, \mathrm{Pb}, \mathrm{Zn}$, and $\mathrm{Tl}$ Traces in Seawater 
Following Flotation Separation. Separation Science andTechnology, 39(11): 2751-2765. https://doi.org/10.1081/SS-200026751

13. Ming, C. and Lena, Q. M. (2001). Comparison of three aqua regia digestion methods for twenty Florida soils. Soil Science Society of America, 65(2).

14. Harrigan, W.F. and MacCance, M.E. (1976). "Laboratory methods in food and dairy microbiology". Academic press. London, New York and San Francisco.

15. Oregon State University Resources (2020). "Microbiology writing guide: presenting data". Culled from http://wic.oregonstate.edu/microbiologywriting-guide-presenting-data/ . Retrieved on $5 / 5 / 2020$

16. Walther, C.; Marwa, K. J.; Seni, J.; Hamis, P.; Silago, V.; Mshana, S. E. and Jande, M. (2016). Microbial contamination of traditional liquid herbal medicinal products marketed in Mwanza city: magnitude and risk factors. Pan African Medical Journal, 23(65):7917

17. AHPA (American Herbal Product Association) (2009). "Heavy Metals: Analysis and Limits in Herbal Dietary and Supplements. AHPA: Silver Spring, MD Nkansah, M.A.; Hayford, S.T.; Borquaye, L.S. and Ephraim J.H (2016). Heavy metal contents of some medicinal herbs from Kumasi, Ghana. Cogent Environment Science 2(1)

18. Edebi, N.V. and Gideon, O.A. (2011) "Evaluation of pharmacognostical parameters and heavy metals in some locally manufactured herbal drugs". Journal of Chemical and Pharmaceutical Research 3(2): 88-97.

19. Bakare-Odunola, M.; Njinga, N.S.; Ayanniyi, R.O.; Bello M.K.; Abdullahi, S.T.; Eniayewu, O.I.; Abdulmajeed, Bello, H.R (2018). "Phytochemical, elemental, antioxidant, antimicrobial and hypoglycemic studies of a mixed herbal product used for the management of diabetics. jpb15(2); 166-174.

20. 'Annual Report of the American Association of Poison Control Centres' (2015). National Poison Data System NPDS.

21. Martin, S. and Griswold, W. (2009) "Human health effects of heavy metals," in Environmental Science and Technology Briefs for Citizens. 15:1-6, Center for Hazardous Substance Research, Manhattan, Kan, USA,
22. Odoh, R. and Ajiboye, O.E. (2019) "Quality Assessment of Some Selected Herbal Medicinal Products Consumed in Wukari, Taraba State". Acta Scientific Microbiology 2(9):28-36

23. Plum, L. M., Rink, L., \& Haase, H. (2010). The Essential Toxin: Impact of Zinc on

24. Human Health. International Journal of Environmental Research and Public Health, 7(4):1342-1365.

25. Ranjan Shivendu, Dasgupta Nandita, Saha Prouil, Rakshit Madhunita, Kmalingam, (2012). Comparative study of antibacterial activity of garlic and cinnamon at different temperature and its application on preservation of fish. Journal of Biotechnology and Biomaterials

26. Olajide, O.A., Olapade. J.T., Makinde J.M. (2003). Anti-inflammatory properties of Combretum miisranthum G. Don (Conbretaceae). Inflammopharmacology; 11(3): 293-8.

27. Anowi, C.F., Cardinal, N.C., Ezugwu, C.O \& Utoh-Nedosa, U.A. (2012). Antimicrobial Properties of the Chloroform Extract of Nauclea latifolia. International Journal of Pharmacy and Pharm Sci 4(2):744-750

28. Padil, V.V.T., Senan, C., \& Cernik, M. (2015). Dodecenylsuccinic anhydride derivatives of gum karaya (Sterculia urens): Preparation, characterization, and their antibacterial properties. Journal of Agricultural and Food Chemistry, 63(14):3757-3765

29. AHPA (American Herbal Product Association) (2014). "Recommended microbial limits for botanical ingredients (cfu/g)"

30. USP: United States Pharmacopeial convention, USP-NF, 37-32 2014.

31. Peter, H, and Pulok, K.M. (2009). "Evaluation of herbal medicinal products" published by Pharmaceutical press, London. Ch 28, p. 401.

32. Tim Sandle (2014). "Fungal contamination of Pharmaceutical products: A growing menace". https://www.europeanpharmaceuticalreview.com/arti cle/24118/fungal-contamination- pharmaceuticalproducts-growing-menace/

33. Onyemelukwe, N.F., Chijokie, O.U., DozieNwakileOgechukwu, Ogboni Sonny Johnbull (2019). "Microbiological, parasitological and lead contamination of herbal medicines consumed in Enugu, Nigeria. Biomed res; 30(6); 828-833. 